\title{
THE IMPACT OF EVAPORATIVE COOLING ON THE THERMOREGULATION AND SENSIBLE HEAT LOSS OF SOWS DURING FARROWING
}

\section{ELIENE JUSTINO ${ }^{1}$, IRENILZA DE A. NÄÄS ${ }^{2}$, THAYLA M. R. CARVALHO ${ }^{3}$, DIEGO P. NEVES ${ }^{4}$, DOUGLAS D'ALESSANDRO SALGADO ${ }^{5}$}

\begin{abstract}
Pigs are more sensitive to high environmental temperatures explained by the inability of sweating and panting properly when compared to other species of farmed livestock. The evaporative cooling system might favor the thermal comfort of animals during exposure to extreme environmental heat and reduce the harmful effects of heat stress. The purpose of this study was to assess the sensible heat loss and thermoregulation parameters from lactating sows during summer submitted to two different acclimatization systems: natural and evaporative cooling. The experiment was carried out in a commercial farm with 72 lactating sows. The ambient variables (temperature, relative humidity and air velocity) and sows physiological parameters (rectal temperature, surface temperature and respiratory rate) were monitored and then the sensible heat loss at 21days lactation was calculated. The results of rectal temperature did not differ between treatments. However, the evaporative cooling led to a significant reduction in surface temperature and respiratory rate and a significant increase in the sow's sensible heat loss. It was concluded that the use of evaporative cooling system was essential to increase sensible heat loss; thus, it should reduce the negative effects of heat on the sows' thermoregulation during summer.
\end{abstract}

KEYWORDS: ventilation, thermal stress, panting, surface temperature, swine, lactation.

\section{IMPACTO DO RESFRIAMENTO EVAPORATIVO NA TERMORREGULAÇÃO E NA TROCA DE CALOR SENSÍVEL DE PORCAS NA MATERNIDADE}

RESUMO: Em comparação com outras espécies de animais de criação comercial, os suínos são mais sensíveis à temperatura ambiente elevada, pois são incapazes de suar, e a respiração ofegante não é eficiente. O sistema de resfriamento evaporativo pode favorecer o conforto térmico dos animais durante a exposição a altas temperaturas e reduzir os efeitos prejudiciais do estresse térmico. Objetivou-se com este estudo avaliar a troca de calor sensível e os parâmetros de termorregulação de porcas em lactação submetidas a dois sistemas de climatização: natural e resfriamento evaporativo, durante o verão. O experimento foi conduzido em uma granja comercial com 72 porcas em lactação, no qual foram monitoradas as variáveis ambientais (temperatura, umidade relativa do ar e velocidade do ar), os parâmetros fisiológicos das porcas (temperatura retal, temperatura superficial e frequência respiratória) e, assim, foi calculada a troca de calor sensível no período de 21 dias de lactação. Os resultados não indicaram efeito significativo dos sistemas de climatização sobre a temperatura retal. Porém, o resfriamento evaporativo proporcionou redução significativa na temperatura superficial e na frequência respiratória, além do aumento significativo na troca de calor sensível das porcas. A utilização do resfriamento evaporativo contribuiu para aumentar a perda de calor sensível, e, portanto, este sistema pode amenizar os efeitos negativos do calor na termorregulação das porcas lactantes durante o verão.

PALAVRAS-CHAVE: ventilação, estresse térmico, respiração ofegante, temperatura de superfície, suínos, lactação.

\footnotetext{
${ }^{1}$ Médica veterinária, Doutora, Faculdade de Engenharia Agrícola, UNICAMP/Campinas - SP, Fone: (19) 983850493, eliene.justino@gmail.com

${ }^{2}$ Eng $^{\circ}$ Civil, Profa. Doutora, Faculdade de Engenharia Agrícola, UNICAMP/Campinas - SP, irenilza@feagri.unicamp.br

${ }^{3}$ Eng $^{\circ}$ Agrícola, Doutora, Faculdade de Engenharia Agrícola, UNICAMP/Campinas - SP, thaylamrcarvalho@hotmail.com

${ }^{4}$ Desenhista Industrial, Doutor, Faculdade de Engenharia Agrícola, UNICAMP/Campinas - SP, diegopneves@gmail.com

${ }^{5}$ Estatístico, Prof. Doutor, Departamento de Matemática, PUC/Campinas - SP, estatdoug@yahoo.com.br

Recebido pelo Conselho Editorial em: 06-5-2013

Aprovado pelo Conselho Editorial em: 04-7-2014
}

Eng. Agríc., Jaboticabal, v.34, n.6, p. 1050-1061, nov./dez. 2014 


\section{INTRODUCTION}

Animals present the necessary mechanisms of heat exchange with the environment, which are non-evaporative/sensible and evaporative/latent. The non-evaporative methods include conduction, convection and radiation, and a balance between the animal body and the environmental temperatures is required for the exchange heat efficacy. The evaporative or latent mechanism include heat loss by evaporation of water through breathing and sweating (change of water state from liquid to gas) and depend on the vapor pressure difference between the environment and the surface of the respiratory tract and/or the skin. Compared to other kind of farmed livestock, pigs are more sensitive to high environmental temperatures explained by the keratinized sweat glands that respond somewhat to the heat stress especially because the fat cover beneath the skin and so they cannot pant enough (THUY, 2005).

Heat exchange by convection and mass transfer is critical in barn structures and influences temperature, humidity and pollutants in the air. According to current literature the adoption of thermal balance is useful to assess ventilation systems, as well as ventilation rates in animal facilities (PAULI et al., 2008; CORDEAU \& BARRINGTON, 2010). A better understanding of the thermal balance might improve the management of barns environmental conditions, which could lead to advance in the pig production process. The environmental control systems in piggeries are designed to ensure the maintenance of good heat balance, and keep animals in thermal comfort. Modern pig houses are designed to keep the animals in their optimal thermal comfort, known by the thermo neutral zone (TNZ), in which the feed can be fully converted into lean tissue efficiently. The TNZ is between the threshold limits of the upper $\left(22^{\circ} \mathrm{C}\right)$ and the lower $\left(12^{\circ} \mathrm{C}\right)$ critical temperatures (BLACK et al., 1993).

The amount of heat exchange with the environment depends on multiple factors, i.e. the production phase, growth and maintenance requirements, pregnancy, lactation, diet composition, stocking density, floor substrate material, enclosure insulation, ambient temperature, humidity, air exchange rate, radiant heat, as well as conduction and convection methods (MARTIN, 2012). All these factors affect the way each animal is influenced by the thermal conditions inside the building. This subjective thermal comfort, also called the "perceived" thermal comfort, can be felt different by different animals. These issues show a lack of adequate control systems in pig houses as its environmental conditions is often outside of the optimal range. Temperature is one of the most influential variable that can affect the health, welfare, and production efficiency of domesticated pigs, and hence the farmer profitability. Therefore, it is necessary to understand the housed livestock responses to the thermal conditions in order to reduce the negative effects of critical temperatures (BANHAZI et al., 2008 a; BANHAZI et al., 2008 b; MARTINS et al., 2008). Under high temperature, the sows reduce feed intake to minimize heat production (KEMP et al., 2011) and increase respiratory rate to dissipate body heat (EICHEN et al., 2008). Amongst the mechanisms to reduce losses due to heat stress it can be highlighted the use of forced ventilation (MORALES et al., 2009), and both floor (LIMA et al., 2011) and evaporative cooling systems over the animals' head, in order to increase the heat loss to the environment and reduce skin temperature (TEIXEIRA et al., 2004; THUY, 2005). It has been proposed a change in many of the older forced-air farrowing facilities, to the use of direct evaporative cooling on the animals' head. BARBARI \& CONTI (2009) found that high air speed and wet floor were preferred by sows during the hottest time of the day. Furthermore, continuously minimum ventilation rate is needed to maintain a healthy environment also for workers inside pig housing (JACOBSON, 2011). A good ventilation might reduce the negative effects of both animals' reproduction and health, increasing feed intake and improving the performance of sows and piglets (MARTIN, 2012).

This study aimed to evaluate the sensible heat loss and the variables related to thermal comfort of lactating sows subjected to evaporative cooling system during the summer season. 


\section{MATERIAL AND METHODS}

\section{Animals and husbandry}

The study was carried out in a commercial farm with 72 sows (DanBred ${ }^{\circledR}$ breed, first to fifth parity) housed in separate farrowing crates in Southwestern Brazil, (latitude $18^{\circ} 1700^{\prime \prime S}$, longitude $46^{\circ} 59^{\prime} 36^{\prime \prime} \mathrm{W}$, and altitude $972 \mathrm{~m}$ ) in the summer season. The study started at sows' parity, and it was conducted during 21 days of lactation until piglets' weaning. Animals were randomly assigned in two treatments with 36 replicates per treatment. The treatments consisted in two acclimatization systems: natural ventilation (NV) and evaporative cooling (EC). Nutrition for warm weather with high energy and low protein was given to the sows (Table 1), supplemented with vegetable oil, sugar and synthetic amino acids. Water was provided ad libitum throughout the study.

TABLE 1. Nutritional composition values of the sow's diet with metabolized energy of 3,391.54 $\mathrm{kcal} \mathrm{kg}^{-1}$.

\begin{tabular}{ll}
\hline Ingredient & Nutritional value (\%) \\
\hline Crude Protein & 17.764 \\
Crude Fiber & 3.411 \\
Ether Extract & 8.575 \\
Ash & 5.723 \\
Calcium & 0.929 \\
Total Phosphorus & 0.647 \\
Digestible Lysine & 1.068 \\
\hline
\end{tabular}

The farrowing rooms had dimensions of $9.58 \mathrm{~m}$ wide, $11.80 \mathrm{~m}$ long and $3.00 \mathrm{~m}$ high. The open sided building was made of concrete blocks; it had polypropylene curtains to close the sides, and the floor was partially galvanized cast iron metal at the end of the pen floor, being the remaining only concrete. Each room had 12 farrowing pens with the dimensions of $1.73 \mathrm{~m}$ wide and $3.38 \mathrm{~m}$ long.

The EC system was set up at the end of farrowing house (Figure 1a), which presented evaporative pads, an axial fan, water tank, circulation system, and water supplier, being all components within a metallic cabinet that supplied the cool air through a polypropylene duct system (Figure 1b). The holes along the ducts were alternated, i.e. within each farrowing room, half of sows received cooled ventilation and another half natural ventilation. The drive system of evaporative cooling was set up to start working when the temperature inside the room reached $\geq$ $23^{\circ} \mathrm{C}$. 


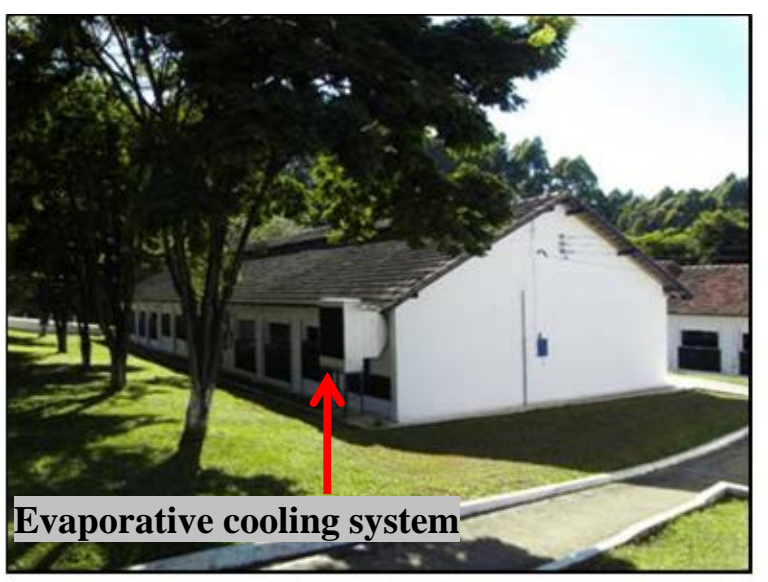

(a)

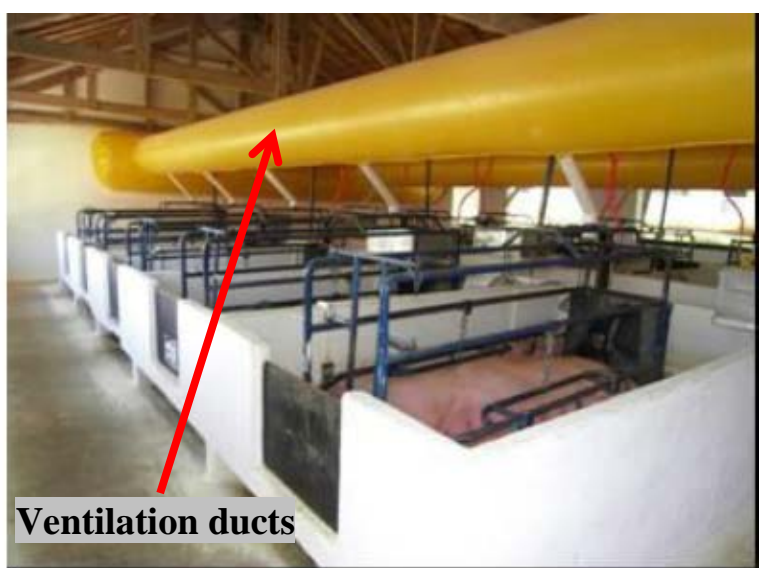

(b)

FIGURE 1. External view of the farrowing barn (a), and interior view of the farrowing crates with ventilation ducts (b).

\section{Experimental Procedure}

Continuous recording and battery-operated data loggers $\mathrm{HOBO}^{\circledR} \mathrm{H} 8$ (Onset Computer Corporation, Inc., Bourne, MA, USA) were used to measure dry bulb temperature (DBT) and relative humidity $(\mathrm{RH})$, both inside and outside of all buildings set to collect data in every 60 min. Data were recorded inside in the geometrical center of the room. Air velocity (AV) was measured twice a day through thermal-hydro-anemometer HTA 4300 model in the morning (7:00 - 9:00 AM) and afternoon (3:00 - 5:00 PM). On the treatment with evaporative cooling, the values of DBT, RH and AV were recorded in the area of sow's head laying down (a) and "standing” (b) position, also with thermal-hydro-anemometer HTA 4300 model.

Sows physiological data (respiratory rate, rectal temperature and surface temperature) were taken twice a day in the morning (7:00 - 9:00 AM) and afternoon (3:00 - 5:00 PM). Respiration rate was determined by timed visual counting of flank movements (breaths $\mathrm{min}^{-1}$ ) by a trained observer. Rectal temperature $\left({ }^{\circ} \mathrm{C}\right)$ was obtained using a veterinary clinical thermometer inserted into the rectum for $1 \mathrm{~min}$. Surface temperature $\left({ }^{\circ} \mathrm{C}\right)$ measurements were registered using a thermographic camera (Testo $880^{\circledR}$, TESTO, INC., Sparta, NJ, USA) covering some body parts (nose, ear, back, chest, lumbar regions, udder, flank, front and rear legs, shin and tail head). In all samples, the thermographic camera was placed at a standardized distance of $3.0 \mathrm{~m}$ from the sow, and the image was recorded with a $45^{\circ}$ angle, encompassing the thermal profile of the whole body (Figure 2). The emissivity index was set to 0.95 on all pictures (BROWN-BRANDL et al., 2012). It was calculated the average surface temperature of the measured points for each sow, during all days of the experiment. We collected 2.880 infrared thermographic images of sows during the experimental period, with 1.440 images per treatment. 


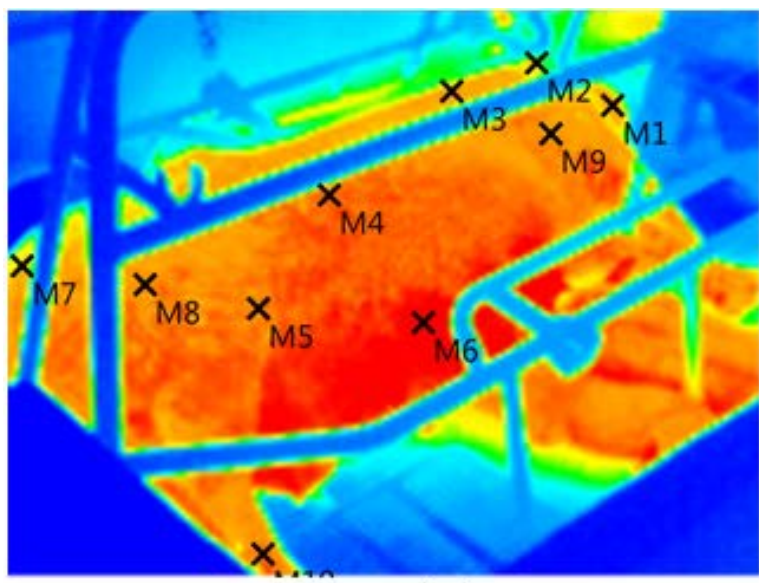

(a)
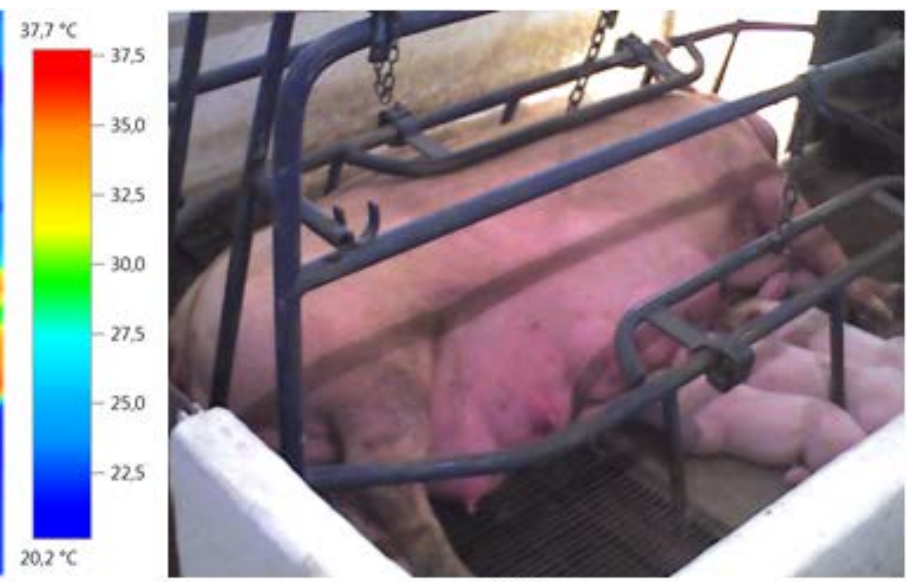

(b)

FIGURE 2. Illustrative thermal (a) and real (b) images of the body parts of a lactating sow.

The thermal images were analyzed through Testo software (IR. Soft $2^{\circledR}$ London, UK), which handle the photo in order to build up histograms plots and calculate the mean and standard deviation of punctual temperatures.

\section{Sensitive heat loss measurement}

For calculating sensible heat loss, the following equations were used: Equation (1) (ALBRIGHT, 1990) presents sensible heat loss according to environment temperature and sow body weight:

$$
Q_{\text {sensible }}=\left\{0.8-\left[\left(\frac{25-D B T}{-5}\right) \times 0.2\right]\right\} \times m
$$

where,

$Q_{\text {sensible }}$ - sensible heat loss, W;

$D B T$ - dry bulb temperature of environment, ${ }^{\circ} \mathrm{C}$, and

$m$ - sow body mass, $\mathrm{kg}$.

The equation (2) (INCROPERA \& DeWITT, 2003) presents sensible heat loss according to heat loss by conduction $\left(Q_{\text {conduction }}\right)$, convection $\left(Q_{\text {convection }}\right)$ and radiation $\left(Q_{\text {radiation }}\right)$ :

$$
Q_{\text {sensible }}=Q_{\text {conduction }}+Q_{\text {convection }}+Q_{\text {radiation }}
$$

Heat loss by conduction was calculated according to the [eq. (3)]:

$$
Q_{\text {conduction }}=\frac{k \times A \times \Delta T}{L}
$$

where,

$\mathrm{k}=$ floor thermal conductivity, $\mathrm{W} \mathrm{m}^{-1} \mathrm{~K}^{-1}$;

$\mathrm{A}=$ sow surface area, $\mathrm{m}^{2}$;

$\Delta \mathrm{T}=$ temperature differential between the sow surface temperature and environmental temperature, $\mathrm{K}$, and

$\mathrm{L}=$ floor thickness, $\mathrm{m}$.

Heat loss by convection was calculated according to the [eq. (4)]: 


$$
Q_{\text {convection }}=h \times A \times \Delta T
$$

where,

$\mathrm{h}=$ coefficient of heat transfer by convection, $\mathrm{W} \mathrm{m} \mathrm{K} \mathrm{K}^{-1}$ (ALBRIGHT, 1990);

$\mathrm{A}=$ sow surface area, $\mathrm{m}^{2}$, and

$\Delta \mathrm{T}=$ temperature differential between the sow surface temperature and environmental temperature, $\mathrm{K}$.

Heat loss by radiation was calculated according to the [eq. (5)]:

$$
Q_{\text {radiation }}=\varepsilon \times A \times \sigma \times\left(T_{s}^{4}-T_{o}^{4}\right)
$$

where,

$\varepsilon=$ material emissivity, dimensionless;

A - sow surface area, $\mathrm{m}^{2}$;

$\sigma=$ Stefan-Boltzmann constant, $\mathrm{W} \mathrm{m}^{-2} \mathrm{~K}^{-4}$;

$\mathrm{T}_{\mathrm{s}}{ }^{4}=$ surface temperature, $\mathrm{K}$, and

$\mathrm{T}_{\mathrm{o}}{ }^{4}=$ environmental temperature, $\mathrm{K}$.

\section{Statistical analysis}

For statistical analysis were used the values for the inside and outside of temperature, relative humidity and air velocity in natural ventilation. For evaporative cooling were used the mean values of temperature, relative humidity and air velocity obtained in the area of sow's head in both position (lying down and standing). Data on rearing ambient conditions and thermoregulation parameters were subjected to the ANOVA, using the software Minitab $15^{\circledR}$ software (Minitab Inc., Pennsylvania; USA)which means were compared by Tukey test considering $5 \%$ of significance $(\mathrm{P}<0.05)$.

\section{RESULTS AND DISCUSSION}

\section{The housing environment}

Results (Table 2) indicated a difference $(\mathrm{P}<0.05)$ in DBT, RH and AV between treatments. The EC treatment showed an average reduction of $2.09{ }^{\circ} \mathrm{C}$ in DBT in the area of sow's head. However, this decrease was not enough to reach the upper critical temperature (UCT) of the thermal comfort zone for lactating sows $\left(22.0^{\circ} \mathrm{C}\right)$, as proposed by BLACK et al. (1993). UCT in the pig means the temperature at which evaporative heat loss begins to increase, particularly from the lungs, through increased respiration rate. Studying thermal conditions on lactating sows, MALMKVIST et al. (2012) observed an increase in rectal temperature, surface temperature and respiratory rate when farrowing room temperature increased from 15.0 to $25.0^{\circ} \mathrm{C}$.

The EC promoted an increase of 9.82\% in RH $(\mathrm{P}<0.05)$, in the area of sow's head, since the cooling equipment was based on water evaporation. The increase in $\mathrm{RH}$ is within the optimum value for pigs (60 to 80\%; BENEDI (1986). The higher air velocity (3.25 m.s $;$; < 0.05) in the area sow's head in EC treatment agreed with BANHAZI et al. (2008a), in which high ventilation rates are required to provide beneficial air velocities. Therefore, it might have some cooling effect during high air temperatures above the comfort zone, especially when the pig's skin is wet and evaporation could occur. 
TABLE 2. Values of mean, standard deviation (SD), minimum and maximum of dry bulb temperature (DBT), relative humidity (RH) and air velocity (AV) inside and outside of the barn according to natural ventilation (NV) and evaporative cooling (EC) treatments.

\begin{tabular}{|c|c|c|c|c|c|c|}
\hline & \multicolumn{2}{|c|}{ Mean \pm SD } & \multicolumn{2}{|c|}{ Minimum Value } & \multicolumn{2}{|c|}{ Maximum Value } \\
\hline & NV & EC & NV & EC & NV & EC* \\
\hline Inside DBT $\left({ }^{\circ} \mathbf{C}\right)$ & $26.25 \pm 0.34 a$ & $24.15 \pm 0.34 b$ & 25.46 & 23.36 & 26.74 & 24.64 \\
\hline Inside RH (\%) & $69.84 \pm 2.69 a$ & $79.54 \pm 2.68 b$ & 64.29 & 73.99 & 72.52 & 82.22 \\
\hline Inside AV $\left(\mathrm{m} \mathrm{s}^{-1}\right)$ & $0.10 \pm 0.01 \mathrm{a}$ & $3.25 \pm 1.05 b$ & 0.01 & 2.70 & 0.15 & 3.90 \\
\hline Outside DBT $\left({ }^{\circ} \mathrm{C}\right)$ & \multicolumn{2}{|c|}{$26.95 \pm 0.65$} & \multicolumn{2}{|c|}{25.75} & \multicolumn{2}{|c|}{27.81} \\
\hline Outside RH (\%) & \multicolumn{2}{|c|}{$67.25 \pm 3.06$} & \multicolumn{2}{|c|}{62.10} & \multicolumn{2}{|c|}{71.14} \\
\hline Outside AV $\left(\mathrm{m} \mathrm{s}^{-1}\right)$ & \multicolumn{2}{|c|}{$0.27 \pm 0.40$} & \multicolumn{2}{|c|}{0.10} & \multicolumn{2}{|c|}{1.02} \\
\hline
\end{tabular}

$\mathrm{a}, \mathrm{b}$ - Different letters in the same line for each variable indicates a significant difference $(\mathrm{P}<0.05)$.

\section{Thermoregulation and sensible heat loss of the sow}

Results indicate that rectal temperatures in both treatments (EC and $\mathrm{NV}$ ) were above $38.6^{\circ} \mathrm{C}$, which is beyond than recommended values for lactating sows in thermal comfort (RENAUDEAU et al., 2001) (Table 3; Figure 3); however, no effect was found for the EC treatment $(\mathrm{P}>0.05)$. Increased respiratory rate and surface temperature may have been sufficient to remove the body heat and avoid an increase in rectal temperature. These findings show that the rectal temperature potentially might be an indicative of heat stress later on, i.e. the response of rectal temperature to the change of body heat content is relatively slow. Previous study suggests that rectal temperature is a valuable indicator that the pigs might have exceeded their thermoregulation capacity (THUY, 2005). This is especially true for pigs subjected to constant high ambient temperature for a long period. Pigs increase their respiratory rate, in order to decrease their total heat production. They also reduce activity, change posture, decrease voluntary feed intake and those actions sometimes are not enough to balance heat loss. A higher rectal temperature is a sign that the pig is experiencing thermal discomfort indicating heat stress on organs and the digestive tract (BANHAZI et. al., 2008 b).

TABLE 3. Mean values, standard deviation (mean \pm SD) and variation coefficient (VC) for the rectal temperature (RT), surface temperature (ST), respiratory rate (RR) and sensible heat loss (SHL) according to natural ventilation (NV) and evaporative cooling (EC) treatments.

\begin{tabular}{lccccc}
\hline & $\begin{array}{c}\text { RT } \\
\left({ }^{\circ} \mathbf{C}\right)\end{array}$ & $\begin{array}{c}\text { ST } \\
\left({ }^{\circ} \mathbf{C}\right)\end{array}$ & $\begin{array}{c}\text { RR } \\
(\mathbf{b p m})\end{array}$ & $\begin{array}{c}\text { SHL - Ref1 } \\
\text { ** }\end{array}$ & $\begin{array}{c}\text { SHL }- \text { Ref2 } \\
(\mathbf{W})\end{array}$ \\
\hline NV & $38.97 \pm 0.34$ & $34.79 \pm 0.43 \mathrm{a}$ & $62.55 \pm 10.81 \mathrm{a}$ & $179.48 \pm 25.79 \mathrm{a}$ & $149.61 \pm 15.56 \mathrm{a}$ \\
EC & $38.81 \pm 0.34$ & $34.33 \pm 0.41 \mathrm{~b}$ & $46.68 \pm 10.58 \mathrm{~b}$ & $198.09 \pm 25.41 \mathrm{~b}$ & $223.95 \pm 23.52 \mathrm{~b}$ \\
VC (\%) & 0.73 & 1.09 & 18.83 & 13.58 & 10.04 \\
\hline
\end{tabular}

a, b - Different letters in the same column for each variable indicates a significant difference $(\mathrm{P}<0.05)$.

${ }^{*}$ Ref1: ALBRIGHT (1990) and Ref2: INCROPERA \& DeWITT (2003).

** bpm: breaths minute ${ }^{-1}$. 


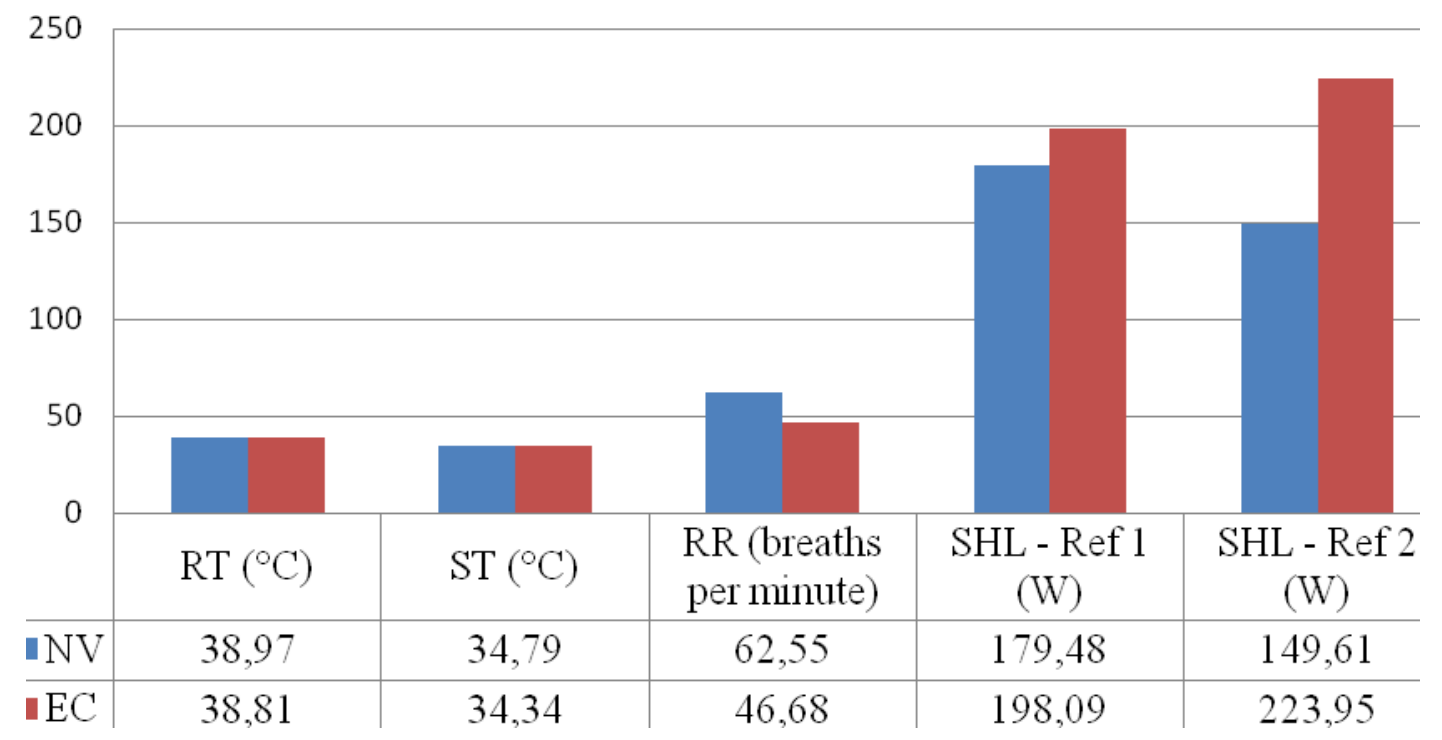

FIGURE 3. Illustrative bar graphic composed by mean values for rectal temperature (RT), surface temperature (ST), respiratory rate (RR) and sensible heat loss (SHL) according to natural ventilation (NV) and evaporative cooling (EC) treatments. Ref 1: ALBRIGHT (1990) and Ref 2: INCROPERA \& DeWITT (2003).

The EC provided significant reduction $(\mathrm{P}<0.05)$ of $0.47^{\circ} \mathrm{C}$ in surface temperature. This result agrees with the observations of JIANG et al. (2004), in which the increase in heat losses by convection and evaporation resulted in lower surface temperature $(\mathrm{P}<0.05)$. Furthermore, the high surface temperature in NV treatment may be explained by the increased blood flow in the skin vessels to increase the body heat dissipation (RENAUDEAU et al., 2001). The study of the gain or loss of heat from the skin surface is of considerable importance in designing the ideal environment to maximize livestock performance. The skin surface temperature increases with the elevation of both temperature and solar radiation, and it decreases with enhanced air velocity. When the skin is moist, the evaporative heat loss increases with increasing temperature, air velocity and solar radiation but decreases with increased relative humidity. MOURA et al. (2011) indicated that the infrared thermography is a precise tool for determining the surface temperature and its association with thermoregulation.

Although in this study, respiratory rate was above of the average value between 15 and 22 bpm (NATIONAL PORK BOARD, 2011) for lactating sow, the evaporative cooling provided reduction of $25.4 \%$ in respiratory rate $(\mathrm{P}<0.05)$. TOLON \& NÄÄS (2005) also found a greater sense of thermal comfort and lower respiratory system on evaporative cooling (50.2 bpm) than on natural ventilation (54.4 bpm), and forced ventilation systems (57.8 bpm). This result is consistent with other studies in which the increase in respiratory rate is the first physiological indicator of the animal response to high ambient temperatures, and should reduce the internal temperature by dissipation of excessive body heat (BANHAZI el. al., 2008 b; EICHEN et al., 2008). Pigs presented a lack of an effective mechanism for cutaneous evaporation, so they must rely on an increase in respiratory rate (BLACK et al., 1993). This response occurs at a lower critical ambient temperature for respiration rate than for rectal temperature as expected since a goal for the activity is to reduce the increase in body temperature. Physiological signs of heat stress occur at low temperatures in modern pigs. These animals under cold stress have high metabolic activity and high heat production, and they appear to have a lower upper critical temperature (BANHAZI et. al., 2008b). Pigs are able to adjust the sensible and latent heat production to maintain a constant total heat production within thermo neutral zone. In previous study PANG et al. (2011) found that respiratory rate and surface temperature of the gestation sows with dripping cool water over head were lower than other reared at natural ventilation. 
Respiratory rate in the present study showed an individual variation (CV of 18.83\%). It can be seen in Figure 4 a negative association between respiratory rate and sensible heat loss, which agrees with results found by JOHNSON \& WICHERN (2001). In both equations of ALBRIGHT (1990) and INCROPERA \& DeWITT (2003) the values of sensible heat loss were lower for natural ventilation since the high heat loss from the lactating sow is due to the latent heat by panting. In the EC treatment both respiratory rate and latent heat were reduced, while the sensible heat loss presented high values. By this approach, it can be stated that the use of the evaporative cooling system improved sows' thermoregulation by helping to dissipate their body heat.
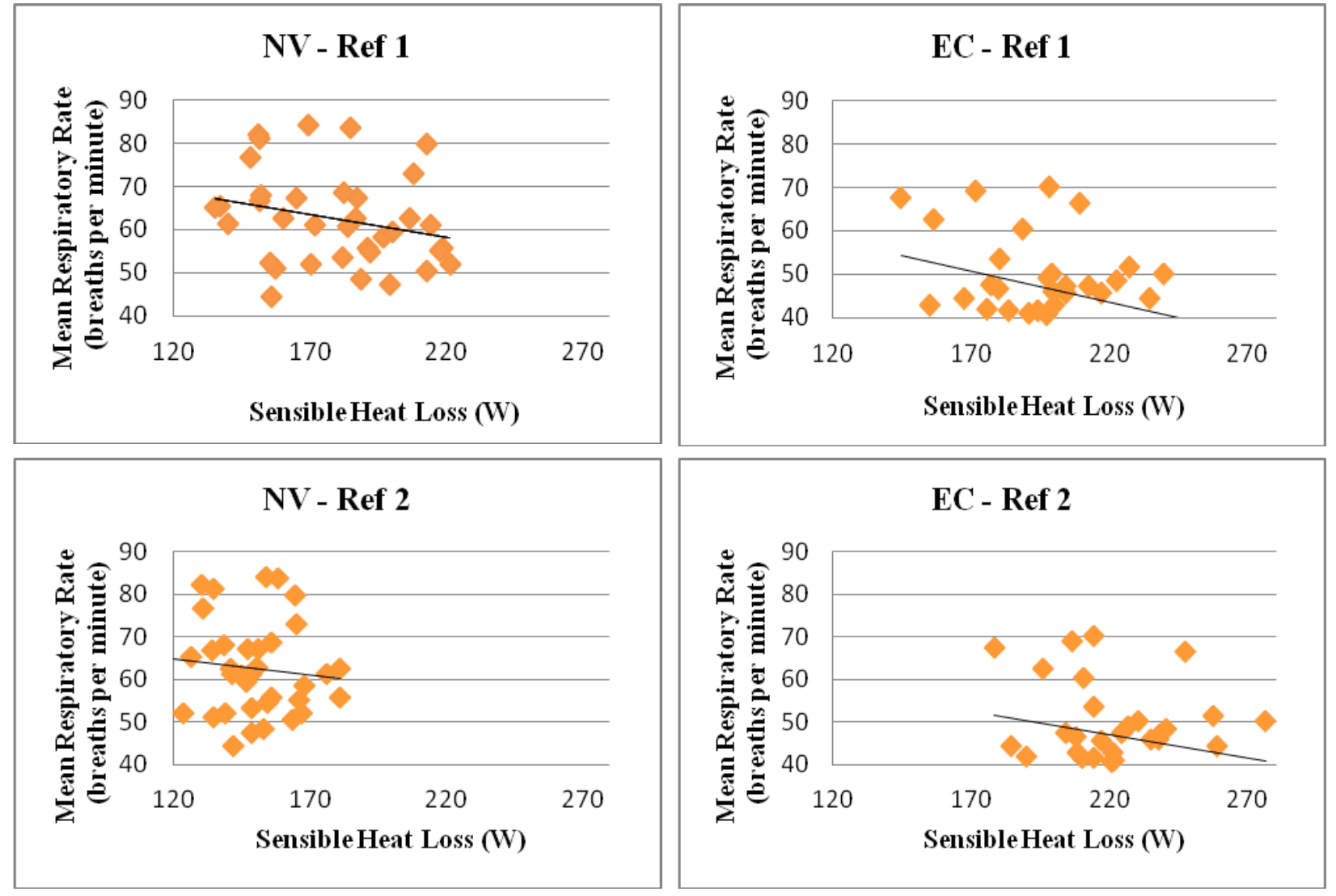

FIGURE 4. Negative association between respiratory rate and sensible heat loss, according to natural ventilation (NV) and evaporative cooling (EC) treatments.

Ref 1: ALBRIGHT (1990) and Ref 2: INCROPERA \& DeWITT (2003).

The findings in this study demonstrated that the sensible heat loss might have a significant role in heat loss depending on the acclimatization system, despite the small temperature gradients between the sow surface and the environment. In addition, the effects of evaporative cooling on sows thermoregulation can be explained partly because as the ambient temperature increases during the day, the RH reduction, which favors the sows' heat loss by convection (MARTIN, 2012). High ambient temperatures strongly affect physiology and heat loss of lactating sows and cooling systems increase animal performance and welfare under high temperature conditions (THUY, 2008). SILVA et al. (2009) found that pigs were more efficient at dissipating body heat by nonevaporative losses (contact with the cooled floor), which proved that the cooled sow performed well due to the increasing sensible heat loss. PANG et al. (2010) found that the water-cooled cover pigs improved the efficiency of sensible heat loss by both radiation and convection exchanges.

Pig production systems, genetics and nutrition have changed in the past 50 years (BROWNBRANDL, 2011). BLOEMHOF et al. (2008) found differences in the relationship between temperature and reproductive performance characteristics, in two genetically different sow lines. 
These differences suggest that the genetic selection on sow heat stress tolerance may be possible (ZUMBACH et al., 2008; BLOEMHOF et al., 2012 and MADZIMURE et al., 2012).

Heat loss to the environment can be increased by floor cooling (LIMA et al., 2011) or increasing air velocity and wetting a greater area of skin (BLACK et al., 1993). The use of cooling system can be used to reduce the negative effects of heat stress on animals (TEIXEIRA et al., 2004; THUY, 2005; AUVIGNE et al., 2010) and acclimation to a particular conditions have a large impact on the animal's heat production, performance and thermoregulatory responses RENAUDEAU et al., 2008).

\section{CONCLUSIONS}

Ambient temperatures above thermal comfort zone strongly affect physiology and heat loss of lactating sows. The use of evaporative cooling system contributed to reduce the negative effects of heat on thermoregulation of the sows by increasing the heat losses compared to natural ventilation system.

\section{ACKNOWLEDGEMENTS}

The authors thank Agroceres Multimix and FAPESP for supporting this research.

\section{REFERENCES}

ALBRIGHT, L.D. Environment control for animals and plants. St. Joseph, American Society of Agricultural Engineers, 1990. 453p.

AUVIGNE, V.; LENEVEU, P.; JEHANNIN, C.; PELTONIEMI, O.; SALLÉ, E. Seasonal infertility in sows: A five year field study to analyse the relative roles of heat stress and photoperiod. Theriogenology, Stoneham, v.74, p.60-66, 2010.

BANHAZI, T.M.; SEEDORF, J.; RUTLEY, D.L.; PITCHFORD W.S. Identification of risk factors for sub-optimal housing conditions in Australian piggeries: Part 3. Environmental parameters. Journal of Agricultural Safety and Health, Adelaide, v.14, n.1, p.41-52, 2008 a.

BANHAZI, T.M., AARNINK, A.; THUY H., PEDERSEN, S.; HARTUNG, J.; PAYNE, H.; MULLAN, B.; BERCKMANS, D. Review of issues related to heat stress in intensively housed pigs. Transaction of the ASABE, St. Joseph, p.737-744, $2008 \mathrm{~b}$.

BARBARI, M.; CONTI, L. Use of different cooling systems by pregnant sows in experimental pen. Biosystems Engineering, Harpenden, v.103, p.239-244, 2009.

BENEDI, J.M.H. El ambiente de los alojamentos ganaderos. Madrid: Ministerio de Agricultura, Pesca Y Alimentación. Servicio de Extensión Agrari, 1986. 28. (Hojas Divulgadoras, n.6/86 hd). 28 p.

BLACK, J.L.; MULLAN, B.P.; LORSCHY, M.L.; GILES, L.R. Lactation in the sow during heat stress. Livestock Production Science, Amsterdam, v.35, p.153-170, 1993.

BLOEMHOF, S.; VAN DER WAAIJ, E.H.; MERKS, J.W.M.; KNOL, E.F. Sow line differences in heat stress tolerance expressed in reproductive performance traits. Journal of Animal Science, Champaign, v.86, n.12, p.3330-3337, 2008.

BLOEMHOF, S.; KAUSE, A.; KNOL, E.F. VAN ARENDONK, J.A.M.; MISZTAL, I. Heat stress effects on farrowing rate in sows: Genetic parameter estimation using within-line and crossbred models. Journal of Animal Science, Champaign, v.90, n.7, p.2109-2119, 2012.

BROWN-BRANDL, T.M.; NIENABER, J.A.; EIGENBERG, R.A.; XIN, H. Heat and moisture production of growing-finishing gilts as affected by environmental temperature. In: ASABE ANNUAL INTERNATIONAL MEETING, 2011, Louisville. Proceedings...Louisville: ASABE, 2011. 
BROWN-BRANDL, T.M.; EIGENBERG, R.A.; PURSWELL, J.L. Determining heat tolerance in finishing pigs using thermal imaging. In: INTERNATIONAL LIVESTOCK ENVIRONMENT SYMPOSIUM, 9., 2012, Valencia. Proceedings... Valencia: ASABE, 2012.

CORDEAU, S.; BARRINGTON, S. Heat balance for two commercial broiler barns with solar preheated ventilation air. Biosystems Engineering, Harpenden, v.107, n.3, p.232-241, 2010.

EICHEN, P.A.; LUCY, M.C.; SAFRANSKI, T.J.; COATE, E.A.; WILLIAMS, A.M.; SPIERS, D.E. Heat stress effects on sow reproductive performance using simulated forced air and evaporative cooling systems. In: LIVESTOCK ENVIRONMENT CONFERENCE, 8., 2008, Foz do Iguaçu, Proceedings... Transaction of ASABE, p.773-779, 2008.

INCROPERA, F.R.; DeWITT, D.P. Fundamentos de Transferência de calor e de massa. Rio de Janeiro: LTC-Livros técnicos e científicos Editora, 2003. 698p.

JACOBSON, L.D. Energy and ventilation management issues in U.S. pig buildings. In: LONDON SWINE CONFERENCE - EXPLORING THE FUTURE, 2011, Ontario. Proceedings... p.117-123.

JIANG, M.; GEBREMEDHIN, K.G.; ALBRIGHT, L.D. Numerical Simulation of Coupled Heat and Mass Transfer through the Hair Coat. In: ASAE/CSAE ANNUAL INTERNATIONAL MEETING, 2004, Ontario. Proceedings...

JOHNSON, R.A., WICHERN, D.W. Applied multivariate statistical analysis. New Jersey: University of Wisconsin, Prentice Hall, 2001.

KEMP, B.; WIENTJES, A.J.; LEEUWEN, V.; HOVING, L.; SOEDE, N. Key factors to improve production and longevity of primiparous sows. In: SIMPÓSIO INTERNACIONAL DE SUINOCULTURA. PRODUÇÃO, REPRODUÇÃO E SANIDADE SUÍNA, 6., 2011, Porto Alegre. Anais... p.13-22, 2011.

LIMA, A.L.; OLIVEIRA, R.F.M.; DONZELE, J.L.; FERNANDES, H.C.; CAMPOS, P.H.R.F.; ANTUNES, M.V.L. Resfriamento do piso da maternidade para porcas em lactação no verão. Revista Brasileira de Zootecnia, Viçosa, MG, v.40, n.4, p.804-811, 2011.

MADZIMURE, J.; CHIMONYO, M.; ZANDER, K.K.; DZAMA, K. Diurnal heat-related physiological and behavioural responses in South African indigenous gilts. Journal of Arid Environments, Cincinatti, v.87, p.29-34, 2012.

MALMKVIST, J.; PEDERSEN, L.J.; KAMMERSGAARD, T.S.; JORGENSEN, E. Influence of thermal environment on sows around farrowing and during the lactation period. Journal of Animal Science, Champaign, v.90, n.9, p.3186-3199, Sep. 2012.

MARTIN, W.R. Effects of heat stress on thermoregulation, reproduction and performance of different parity sows. 2012. 154f. Thesis (Master of Science) - Faculty of the Graduate School University of Missouri, Missouri, 2012.

MARTINS, T.D.D.; COSTA, A.N.; SILVA, J.H.V. Respostas termorreguladoras de matrizes suínas híbridas em lactação, mantidas em ambiente quente. Ciência agrotécnica, Lavras, v.32, n.3, p.961968, 2008.

MINITAB. Versão 15.1.0.0. Inc. 2005.

MORALES, O.E.S.; GONÇALVES, M.A.D.; STORTI, A.A.; BERNARDI, M.L.; WENTZ, I.; BORTOLOZZO, F.P. Aspectos produtivos de fêmeas suínas e suas leitegadas em diferentes sistemas de ambiência na maternidade. In: CONGRESSO BRASILEIRO DE VETERINÁRIOS ESPECIALISTAS EM SUÍNOS, 14., 2009. Uberlândia. Anais... p.265-266.

MOURA, D.J.; MAIA, A.P.A.; VERCELLINO, R.A.; MEDEIROS, B.B.L.; SARUBBI, J.; GRISKA, P.R. Uso da termografia infravermelha na análise da termorregulação de cavalo em treinamento. Engenharia Agrícola, Jaboticabal, v.31, n.1, p.23-32, jan/fev. 2011. 
NATIONAL PORK BOARD. Provide proper swine care to improve swine well-being: ventilation. Des Moines: In Swine Care Handbook, 2011. P. 98-99.

PANG, Z.; LI, B; XIN, H.; YUAN, X.; WANG, C. Characterization of an experimental watercooled cover for sows. Biosystems Engineering, Harpenden, v.105, p.439-447, 2010.

PANG, Z.; LI, B.; XIN, H.; XI, L.; CAO. W.; WANG, C. LI. W. Field evaluation of a water-cooled cover for cooling sows in hot and humid climates. Biosystems Engineering, Harpenden, v.110, p.413-420, 2011.

PAULI, D.G.; SILVA, J.N.; VIGODERIS, R.B.; TINOCO, I.F.F.; GALVARRO, S.F.S.

Desenvolvimento de um software para o dimensionamento de sistemas de ventilação e resfriamento evaporativo em instalações avícolas climatizadas. Revista Engenharia na Agricultura, Viçosa, MG, v.16, n.2, p. 167-179, 2008.

RENAUDEAU, D.; QUINIOU, N.; NOBLET, J. Effects of exposure to high ambient temperature and dietary protein level on performance of multiparous lactating sows. Journal of Animal Science, Champaign, v.79, p.1240-1249, 2001.

RENAUDEAU, D.; KERDONCUFF, M.; ANAÏS, C.; GOURDINE, J.L. Effect of temperature level on thermal acclimation in Large White growing pigs. Animals, London, v.2, n.11, p.16191626, 2008.

SILVA, B.A.N.; OLIVEIRA, R.F.M.; DONZELE, J.L.; FERNANDES, H.C.; LIMA, A.L.; RENAUDEAU, D.; NOBLET, J. Effect of floor cooling and dietary amino acids content on performance and behaviour of lactating primiparous sows during summer. Livestock Science, Amsterdam, v.120, p.25-34, 2009.

TEIXEIRA, V.H.; TEIXEIRA, A.S.; LOPES, S.P. Efeito do resfriamento adiabático evaporativo e da ventilação forçada no desempenho de porcas lactantes e suas leitegadas. Engenharia na Agricultura, Viçosa, MG, v.12, n.1, p.51-56, 2004.

THUY, H.T.T. Heat stress in growing pigs. 2005. 163f. Thesis (PhD). Wageningen Institute of Animal Science, Wageningen University, Wageningen, 2005.

TOLON, Y.B; NÄÄS, I.A. Avaliação de tipos de ventilação em maternidade de suínos. Engenharia Agrícola, Jaboticabal, v.25, n.3, p.565-574, 2005.

ZUMBACH, B.; MISZTAL, I.; TSURUTA, S.; SANCHEZ, J.P.; AZAIN, M.; HERRING, W.; HOLL, J.; LONG, L.; CULBERTSON, M. Genetic components of heat stress in finishing pigs: development of a heat load function. Journal of Animal Science, Champaign, v.86, p.2082-2088, 2008. 